\title{
STUDY OF THE MECHANISM OF ACTION OF MODULATED UHF SIGNAL ON A SPHERICAL NON-IDEAL DIELECTRIC MODEL
}

\author{
A.O. Golovenko, golan94@mail.ru, \\ A.A. Kopyrkin, iodo108@mail.ru, \\ V.I. Tambovtsev, tamboval@mail.ru \\ South Ural State University, Chelyabinsk, Russian Federation
}

\begin{abstract}
The work belongs to the field of electrodynamics and electromagnetic compatibility. The conversion of microwave radiation passing through a non-ideal dielectric and its concentration in the dielectric region is analyzed. The results of the study of the mechanism of modulated microwave radiation when exposed to a spherical non-ideal dielectric are presented. The mathematical apparatus on the basis of which modeling was carried out is given. The study was carried out by means of computer simulation in CAD CST Studio Suite that combines a rich set of tools for low and high frequency modelling and solution of problems of electrodynamics. The effect of microwave radiation focusing when exposed to a spherical non-ideal dielectric of the modulation type and depth is studied. The results of the influence of frequency-amplitude-pulse-modulated microwave signals on a spherical non-ideal dielectric were obtained. It is shown that the radiation is linearly frequencymodulated signal, there is a concentration of radiation to a small area of the dielectric, put forward the theory on the ability to control the location of concentration of the radiation by changing its parameters. The paper presents the parameters of the spherical non-ideal dielectric, such as dielectric permittivity, conductivity, loss tangent, etc. are the parameters of the modulated microwave signals. The practical significance of the obtained results is explained.
\end{abstract}

Keywords: CST, modulated signals, non-ideal dielectric model, FDTD method, radiation focusing.

\section{Introduction}

This article analyzes the dependence of the concentration of microwave radiation in a spherical nonideal dielectric (the theoretical model of the brain) on the form of modulation of the radio frequency signal in order to detect the localization of the electromagnetic field in the sections of the spherical model. The paper proposes the implementation and construction of a mathematical model of the brain, as well as a dipole antenna. Also, possibility of application of results in such areas as radiolocation, medicine (treatment of neurodegenerative diseases) is justified.

In 1956, it was observed that people who happened to be in the radar area felt auditory hallucinations, even if the ears were protected by noise suppressors. The subjects were alternately placed behind a screen with a quarter-wavelength hole 1.5 to $2.0 \mathrm{~m}$ from the antenna horn. The $500 \mathrm{KW}$ transmitter operated at $1.3 \mathrm{GHz}$, a pulse duration of $2 \mu \mathrm{s}$ and a repetition rate of $600 \mathrm{~Hz}$ (the power is given for the radio impulse). The poll showed that the sounds are felt on the harmonics, and the fundamental frequency is absent. The results of systematic observations and first studies were published in 1961 by Alan Frey [1], and the microwave auditory phenomenon was called Frey's radio-sound effect.

In earlier works and later publications devoted to the study of the effect of radio sound there is, as a rule, the focus on the physiological track preparation of this phenomenon is associated with the peculiarities of either the auditory system or direct the influence of modulated microwave electromagnetic field on brain structures [2].

In modern publications mechanisms of interaction of the modulated high-frequency signal with weakly absorbing substance for the purpose of detection of electroacoustic effect are Considered and analyzed $[3,4]$.

In this paper, we tried to simulate this effect, where a spherical non-ideal dielectric is used as the head model. We also analyzed the propagation of electromagnetic waves. 


\section{The FDTD method for electrodynamic calculations of impact electromagnetic field} on model of head

In this paper, a numerical study of the interaction of electromagnetic radiation and the user's head was conducted using the CST Microwave Studio (CST MS) program. This program is based on the FDTD method and allows finding all required field characteristics in the near and far zones. Since in this simulation environment there is an opportunity to produce the necessary electrodynamic calculations using the finite difference method in the time domain.

By selecting different types of modulation and its parameters, it is possible to provide the radiation concentration in the necessary region of the dielectric. A dipole antenna was used in the simulation. It is worth noting that with deviation of the frequency of the chirp signal of less than $10 \%$, the horn antenna can be replaced with a vibratory antenna, as was done in the study to increase the calculation speed. As a model of a non-ideal dielectric, a spherical model of the brain (the average size) was chosen for research $[5,6]$. This is a simplified model, consisting of skin and bone layers and the brain itself. This model makes it possible to visually examine the mechanism of the action of the emitted microwave signal.

The following formulas necessary for our calculations are derived from Maxwell's basic equations discovered and proved by him at the beginning of the nineteenth century [7].

The final equations of the electromagnetic field for a spherical non-ideal dielectric (1), (2), obtained from Maxwell's equations, it looks like this:

$$
\begin{aligned}
& H_{x}^{\sigma}(I, J, K)^{(n+1)}=H_{x}^{o}(I, J, K)^{n} e^{\left(-\sigma+\frac{\Delta t}{\mu}\right)}+\left(1-e^{\left(-\sigma+\frac{\Delta t}{\mu}\right)}\right)-\left(-H_{x}^{\sigma}(I, J, K)^{\left(n+\frac{1}{2}\right)}-\frac{\mu-\mu_{0}}{\sigma^{*}} H_{x}^{\sigma}(I, J, K)^{\left(n+\frac{1}{2}\right)}-\right. \\
& \left.-\left(E_{z}^{\sigma}(I, J+1, K)^{\left(n+\frac{1}{2}\right)} J-\frac{E_{z}^{\sigma}(I, J, K)}{\left(\sigma^{*}\left(Y_{0}(J+1)-Y_{0}(J)\right)\right.}+E_{y}^{\sigma}(I, J, K+1)^{\left(n+\frac{1}{2}\right)} J-\frac{\left(E_{y}^{\sigma}(I, J, K)\right.}{\sigma^{*}\left(Z_{0}\left(K+\frac{1}{2}\right)\right.}\right)\right) \\
& E_{x}^{\sigma}(I, J, K)^{(n+1)}=E_{x}^{\sigma}(I, J, K)^{\left(n+\frac{1}{2}\right)} e^{\left(-\sigma+\frac{\Delta t}{\mu}\right)}+\left(1-e^{\left(-\sigma+\frac{\Delta t}{\mu}\right)}\right)-E_{x}^{\sigma}(I, J, K)^{n}-\frac{\varepsilon-\varepsilon_{0}}{\sigma^{*}} E_{x}^{o}(I, J, K)^{n}+ \\
& +\left(H_{z}^{\sigma}(I, J, K)^{n}-\frac{H_{z}^{\sigma}(I, J-1, K)^{n}}{\sigma^{*}(Y(J)-Y(J-1)}-\left(H_{y}^{\sigma}(I, J, K)^{n}-\frac{H_{y}^{o}(I, J, K-1)^{n}}{\left(o^{*}(Z(K)-Z(K-1))\right.},\right.\right.
\end{aligned}
$$

where $H$ - the vector of the magnetic field strength; $E$ - the electric field strength vector; $I, J, K, x, y-$ are the spatial coordinates; $\varepsilon, \mu$-dielectric and magnetic permeability of the medium.

In the theoretical aspect, we have a circular waveguide, in which, during the passage of a monochromatic signal, the $E_{11}$ wave concentration occurs according to Fig. 1 [8].
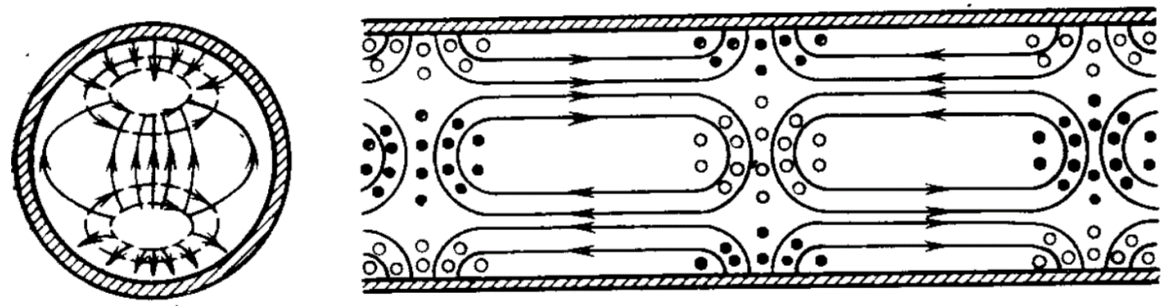

Fig. 1. Distribution of the wave $E_{11}$ in a circular waveguide

By choosing different modulation types and parameters, it is possible to provide concentration of the radiation in the desired region of the dielectric. Dipole antenna was used for modeling. It is worth noting that when the frequency deviation of the LFM signal less than $10 \%$ horn antenna can be replaced by a vibrator, as was done in the study to increase the calculation speed.

As a model of non-ideal dielectric, a spherical model of the brain (average size) was chosen for the research. This is a simplified model consisting of the skin and bone layers and the brain itself. This model allows you to visually examine the mechanism of action of the emitted microwave signal. 


\section{Краткие сообщения}

We present the simulation results when radiation is a monochromatic signal, shown in Fig. 2, 3 and LFM signal, in the Fig. 4, 5.

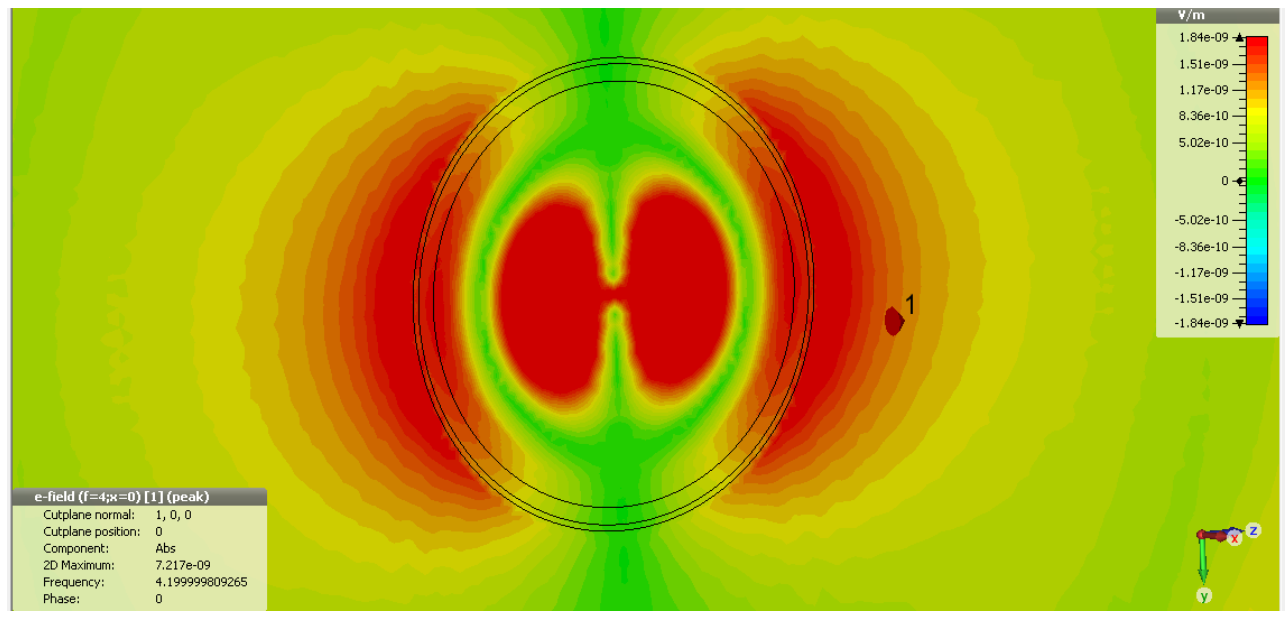

Fig. 2. Field strength in the vertical plane when a monochromatic signal is emitted

In the course of the simulation, we obtained that when the unmodulated signal is emitted, the concentration of the electromagnetic field in the dielectric resembles the concentration of the $E_{11}$ wave in a circular waveguide [8].

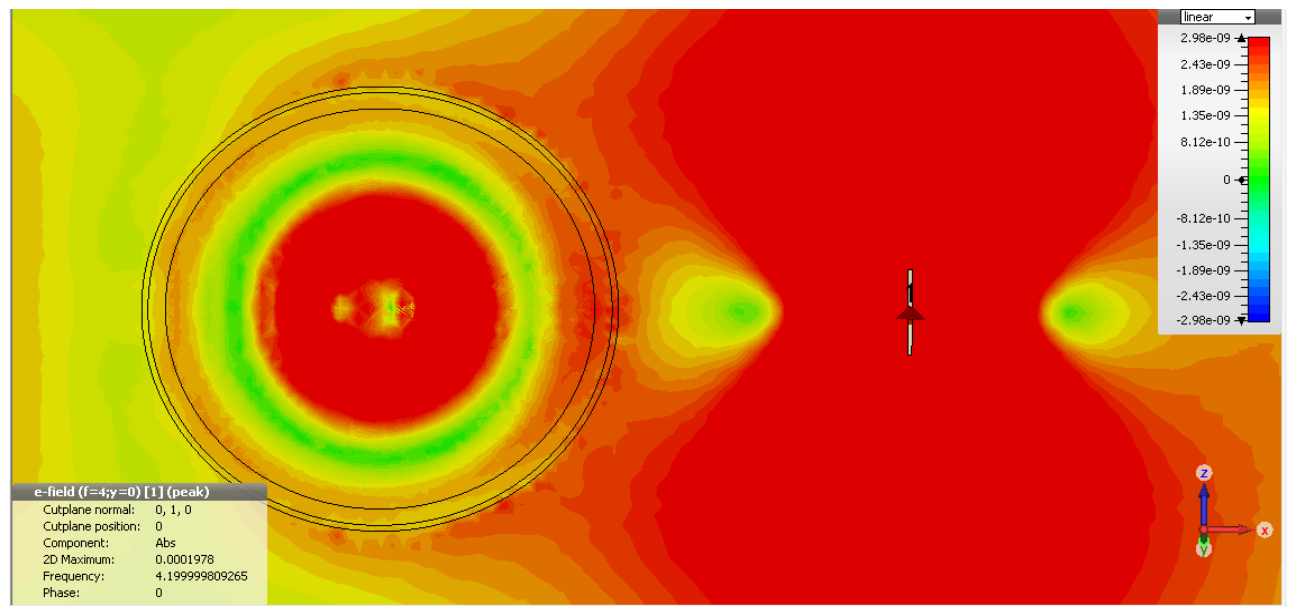

Fig. 3. Field strength in the horizontal plane when a monochromatic signal is emitted

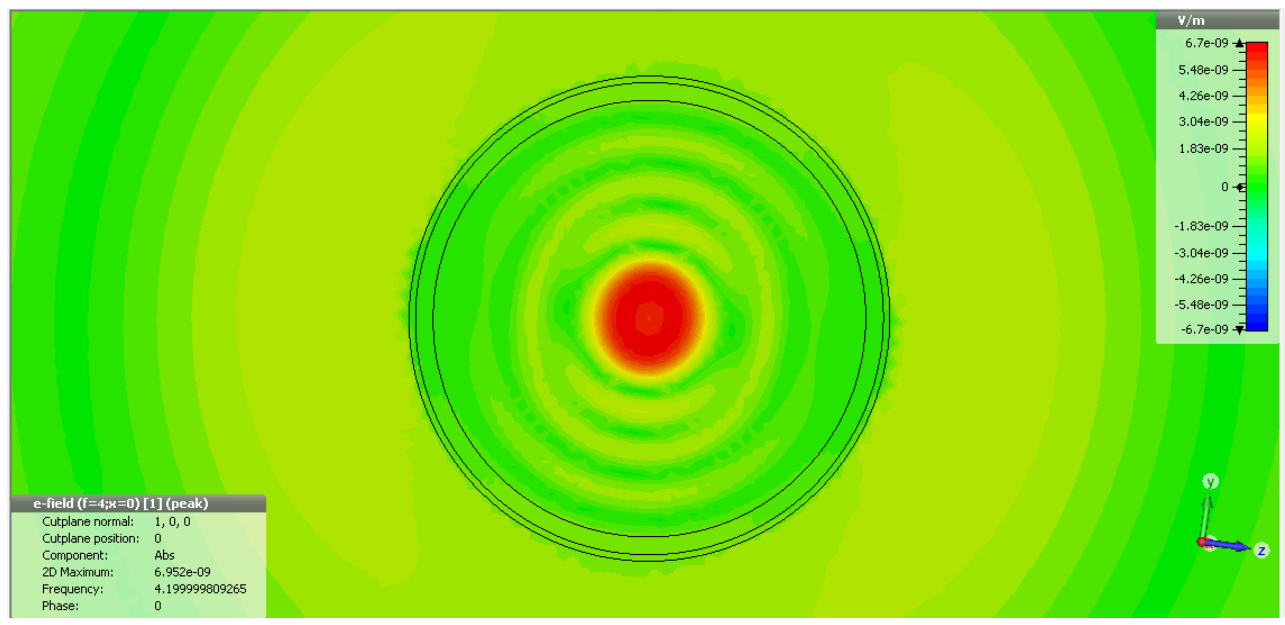

Fig. 4. Field strength in the vertical plane during the emission of the LFM signal 


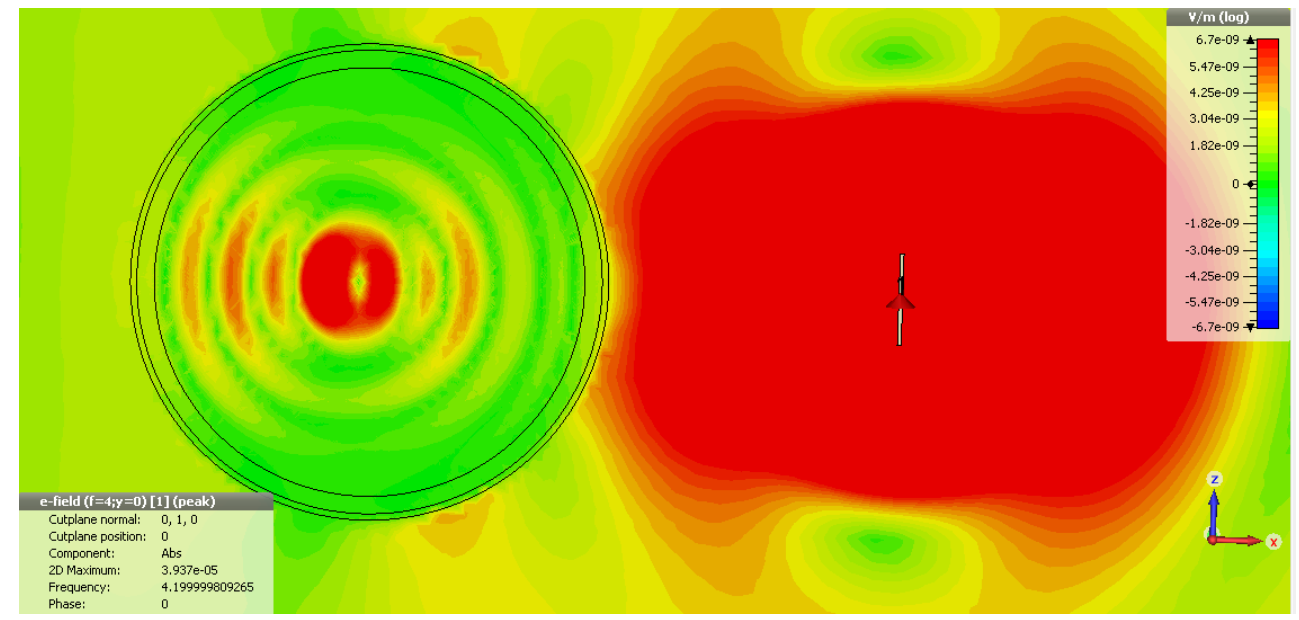

Fig. 5. Field strength in the horizontal plane during the emission of the LFM signal

The human head as a biological body has a rather complex structure and consists of several types of biological tissue with losses, in which the power is absorbed unevenly because of the difference in the conductivity of each layer. Therefore, an accurate construction of the head model is an important condition for the accuracy of the calculation of the internal field [9]. The averaged values of the main parameters of the frequently used three-layer model of the human head are presented in Table 1.

Table 1

The parameters of the three-layer model of the human head

\begin{tabular}{|l|c|c|c|c|c|}
\hline Substance & $\begin{array}{c}\text { Thickness, } \\
\mathrm{mm}\end{array}$ & $\begin{array}{c}\text { Relative dielectric } \\
\text { permittivity, } \\
\mathrm{GHz}\end{array}$ & $\begin{array}{c}\text { Conductivity } \\
\text { of the layer, } \\
\mathrm{Sm} / \mathrm{m}\end{array}$ & $\begin{array}{c}\text { The density } \\
\text { of layers, } \\
\mathrm{kg} / \mathrm{m}^{3}\end{array}$ & $\begin{array}{c}\text { Thermal } \\
\text { conductivity, } \\
\mathrm{W} / \mathrm{K} / \mathrm{m}\end{array}$ \\
\hline Brain & fill & 53 & 1.1 & 1030 & 0.3 \\
\hline Bone & 3 & 9 & 0.06 & 1800 & 0.01 \\
\hline Skin & 1 & 59 & 1.3 & 1100 & 0.5 \\
\hline
\end{tabular}

\section{Conclusion}

The following conclusions can be drawn from the results obtained. The LFM signal is focused primarily at the center of the dielectric, in the horizontal plane there are side regions of radiation concentration in the form of circles, the distance between which depends on the frequency of deviation.

It must also be taken into account that the voltage of the source operating at the antenna input varies with time. Therefore, for each time step, it is necessary to calculate the values of the electric and magnetic fields at all points of the analyzed space, in accordance with the time domain method (FDTD method).

The use of the FDTD method is particularly advantageous in the study of non-stationary processes for example, the electromagnetic field of antennas when excited by short pulses or modulated signals.

This study will help in predicting the treatment of such diseases in which it is necessary to affect specific areas of the brain. In radar, when studying the wobbling of a modulated signal on a spherical object.

Further research will consist in the complication of the model, the use of a horn antenna and a phased array, the use of a supercomputer.

\section{References}

1. Frey Allan. Auditory System Response to Radio Frequency Energy. Aerospace Med, 1961, 32, pp. $1140-1142$.

2. Elder J.A., Chou C.K. Auditory Response to Pulsed Radiofrequency Energy. Bioelectromagnetics, 2003, 24, pp. 162-173. DOI: 10.1002/bem.10163

3. Higdon R.L. Absorbing Boundary Conditions for Difference Approximations to the Multidimensional Wave Equation. Math. Comp., 1986, vol. 47, pp. 437-459. DOI: 10.2307/2008166 
4. Barinov A.E., Tambovtsev V.I., Kydyrbaeva D.A. [Coagulation of Blood Cells on Microwave Exposure]. Fizika i tekhnicheskie prilozheniya volnovykh protsessov. Materialy XIII Mezhdunarodnoi konferentsii [Physics and Technology of Wave Processes. Proceedings of the XIII International Conference]. Kazan' - Samara, 2015, pp. 353-355. (in Russ.)

5. Budden K.G. The Waveguide Mode Theory of Wave Propagation. Logos Press, London, 1961. $325 \mathrm{p}$.

6. Terman F.E. Electronic and Radio Engineering. McGraw-Hill Book Company, New York, 1955. $1078 \mathrm{p}$.

7. Kunz K., Luebbers R. The Finite Difference Time Domain for Electromagnetics, 1993, pp. 90-91. DOI: $10.1201 / 9780203736708$

8. Semenov N. A. Tekhnicheskaya elektrodinamika. Uchebnik dlya vuzov [Technical Electrodynamics. Textbook for High Schools]. Moscow, Link Publ., 1973. 480 p.

9. IEEE C95.1-1991, IEEE Standard for Safety Levels with Respect to Human Exposure to Radio Frequency Electromagnetic Fields, $3 \mathrm{kHz}$ to $300 \mathrm{GHz}$. New York: The Institute of Electrical and Electronics Engineers, Inc., April 1992. Available at: https://standards.ieee.org/standard/C95_1-1991.html.

Received 26 February 2018

Удк 621.372.2 + 621.371.39

DOI: $10.14529 /$ ctcr190114

\title{
ИССЛЕДОВАНИЕ МЕХАНИЗМА ВОЗДЕЙСТВИЯ \\ МОДУЛИРОВАННОГО СВЧ-СИГНАЛА НА СФЕРИЧЕСКИЙ НЕИДЕАЛЬНЫЙ ДИЭЛЕКТРИК
}

\author{
А.О. Головенко, А.А. Копыркин, В.И. Тамбовцев \\ Южно-Уральский государственный университет, г. Челябинск, Россия
}

\begin{abstract}
Работа относится к области электродинамики и электромагнитной совместимости. Анализируется преобразование микроволнового излучения при прохождении через неидеальный диэлектрик и его концентрация в области диэлектрика. Представлены результаты исследования механизма модулированного СВЧ-излучения при его воздействии на сферически неидеальный диэлектрик. Приведен математический аппарат, на основе которого проводилось моделирование. Исследования производились посредством компьютерного моделирования в CAПP CST Studio Suite, который объединяет в себе широкий набор инструментов для низкочастотного и высокочастотного моделирования и решения задач электродинамики. Исследуется эффект фокусировки СВЧ-излучения при воздействии на сферический неидеальный диэлектрик от вида и глубины модуляции. Были получены результаты воздействия частотноамплитудно-импульсно-модулированных СВЧ-сигналов на сферический неидеальный диэлектрик. Показано, что при излучении линейно-частотно-модулированного сигнала происходит концентрация излучения небольшой области диэлектрика, выдвинута теория о возможности управления месторасположением концентрации данного излучения путем изменения его параметров. В работе приводятся параметры сферического неидеального диэлектрика, такие как диэлектрическая проницаемость, проводимость, тангенс угла потерь и т. д. Также приводятся параметры модулированных СВЧ-сигналов. Объясняется практическая значимость полученных результатов.

Ключевые слова: CST, модулированные сигналь, неидеальный диэлектрик модель, метод FDTD, фокусировка излучения.
\end{abstract}




\section{Лumepamypa}

1. Frey, Allan. Auditory system response to radio frequency energy / Allan Frey // Aerospace Med. 1961. - 32. - P. 1140-1142.

2. Elder, J.A. Auditory Response to Pulsed Radiofrequency Energy / J.A. Elder, C.K. Chou // Bioelectromagnetics. - 2003. - 24. - P. 162-173. DOI: 10.1002/bem.10163

3. Higdon, R.L. Absorbing boundary conditions for difference approximations to the multidimensional wave equation / R.L. Higdon // Math. Comp. - 1986. - Vol. 47. - P. 437-459. DOI: $10.2307 / 2008166$

4. Баринов, А.Е. Коагуляция частии крови под воздействием СВЧ излучения / А.Е. Баринов, В.И. Тамбовиев, Д.А. Кыдырбаева // Материаль ХІІІ Международной конференции «Физика и технические приложения волновых прочессов». - Казань; Самара, 2015. - С. 353-355.

5. Budden, K.G. The Waveguide Mode Theory of Wave Propagation / K.G. Budden. - London: Logos Press, 1961. - 325 p.

6. Terman, F.E. Electronic and Radio Engineering / F.E. Terman. - New York: McGraw-Hill Book Company, 1955. $-1078 \mathrm{p}$.

7. Kunz, K. The Finite Difference Time Domain for Electromagnetics / K. Kunz, R. Luebbers. 1993. - P. 90-91. DOI: 10.1201/9780203736708 $480 \mathrm{c}$.

8. Семенов, Н.А. Техническая электродинамика: учеб. для вузов / Н.А. Семенов. - М., 1973. -

9. IEEE C95.1-1991, IEEE Standard for Safety Levels with Respect to Human Exposure to Radio Frequency Electromagnetic Fields, $3 \mathrm{kHz}$ to $300 \mathrm{GHz}$. - New York: The Institute of Electrical and Electronics Engineers, Inc., 1992. - https://standards.ieee.org/standard/C95_1-1991.html.

Головенко Антон Олегович, аспирант кафедры системного программирования, ЮжноУральский государственный университет, г. Челябинск; golan94@mail.ru.

Копыркин Александр Андреевич, аспирант кафедры общей и теоретической физики, ЮжноУральский государственный университет, г. Челябинск; iodo108@mail.ru.

Тамбовцев Владимир Иванович, д-р физ.-мат. наук, профессор кафедры инфокоммуникационных технологий, Южно-Уральский государственный университет, г. Челябинск; tamboval@ mail.ru.

Поступила в редакцию 26 февраля 2018 г.

\section{ОБРАЗЕЦ ЦИТИРОВАНИЯ}

Golovenko, A.O. Study of the Mechanism of Action of Modulated UHF Signal on a Spherical Non-Ideal Dielectric Model / A.O. Golovenko, A.A. Kopyrkin, V.I. Tambovtsev // Вестник ЮУрГУ. Серия «Компьютерные технологии, управление, радиоэлектроника». - 2019. - Т. 19, № 1. - С. 146-151. DOI: $10.14529 /$ ctcr190114

\section{FOR CITATION}

Golovenko A.O., Kopyrkin A.A., Tambovtsev V.I. Study of the Mechanism of Action of Modulated UHF Signal on a Spherical Non-Ideal Dielectric Model. Bulletin of the South Ural State University. Ser. Computer Technologies, Automatic Control, Radio Electronics, 2019, vol. 19, no. 1, pp. 146-151. DOI: $10.14529 /$ ctcr190114 